\title{
Prevalencia de deterioro cognitivo en mayores de 70 años ingresados en un Servicio de Medicina Interna
}

\author{
A. MARQUÈS, J. P. RODRÍGUEZ, O. L. CAMACHO \\ Clínica Sociosanitaria. Hospital Sagrat Cor GHSCJ-SSM. Martorell, Barcelona
}

\author{
PREVALENCE OF COGNITIVE DECLINE IN PEOPLE OLDER THAN \\ 70 YEARS ADMITTED IN AN INTERNAL MEDICINE SERVICE
}

\section{RESUMEN}

Fundamento: El deterioro cognitivo (DC) de los ancianos es una causa importante de sobrecargas de los cuidadores y del personal asistencial. Por otro lado es un marcador de mal pronóstico, favorece diferentes síndromes geriátricos e incrementa el riesgo de institucionalización. Su detección precoz puede ser beneficiosa, tanto para el enfermo como para sus familiares, ya que algunas causas de DC tienen tratamiento y además permite planificar la atención y seguimiento futuros.

El objetivo de este trabajo es medir la prevalencia de DC, antes del comienzo de la patologia aguda que motiva su ingreso hospitalario, en pacientes mayores de 70 años ingresados en un Servicio de Medicina Interna de un hospital comarcal.

Pacientes y métodos: Estudio prospectivo realizado en el Servicio de Medicina Interna del Hospital de Mataró, en 100 pacientes mayores de 70 años, elegidos de forma aleatoria. Se evalúa la presencia de DC, con la escala de Blessed, durante el mes previo al inicio de la enfermedad que motiva el ingreso.

Resultados: el $43 \%$ de los pacientes tenían DC (42\% de los hombres y $44 \%$ de las mujeres). En los mayores de 80 años la prevalencia de DC era superior al $60 \%$.

Conclusiones: A partir de los 70 años muchos de los pacientes ingresados en un Servicio de Medicina Interna tienen criterios de DC, previo al inicio de la enfermedad aguda. Su diagnóstico, estudio y tratamiento precoz permitiría mejorar la calidad asistencial en estos pacientes.

PALABRAS CLAVE: Deterioro cognitivo. Prevalencia. Anciano. Calidad asistencial.

\section{ABSTRACT}

Background: Cognitive decline in older people is an important cause of burden for caregivers and assistance staff. It is a poor prognosis marker that favors the onset of different geriatric syndromes and increases the risk of institutionalization.

As some causes of cognitive decline can be treated, its early diagnosis is fundamental for patients and caregivers. This, help us to design a care plan and a future follow up.

The objective of this article is to measure the prevalence of Cognitive Decline before the onset of the acute disease that led patients older than 70 years, to an admission at the Internal Medicine Service.

Patients and methods: a prospective randomized study was performed in the Internal Medicine Service of the Hospital de Mataro, which included 100 patients older than 70 years. Presence of Cognitive Decline was evaluated through the Blessed Scale during the previous month of the onset of the disease that motivated the admission.

Results: $43 \%$ of the patients had Cognitive Decline $(42 \%$ male and $44 \%$ female). The prevalence of $C D$ in patients older than 80 years was over $60 \%$.

Conclusions: Many of the admitted patients of an Internal Medicine Service older than 70 years had criteria for Cognitive Decline before the onset of the acute disease. Its diagnosis, study and therapeutic plan before the patient's discharge is a great opportunity to improve the quality of assistance.

KEY WORDS: Cognitive decline. Prevalence. Older people. Quality of assistance.

Marquès A, Rodríguez JP, Camacho OL. Prevalencia de deterioro cognitivo en mayores de 70 años ingresados en un Servicio de Medicina Interna. An Med Interna (Madrid) 2004; 21: 123-125.

\section{INTRODUCCIÓN}

El deterioro cognitvo (DC), cuya identificación forma parte de la valoración geriátrica integral, es reconocido por todos los expertos como marcador de fragilidad y como factor de riesgo de utilización de recursos sanitarios y sociosanitarios (1-4). Si además se asocian trastornos de conducta, se ensombrece el pronóstico y se incrementa la sobrecarga a familiares y cuidadores $(5,6)$.

El presente trabajo analiza la prevalencia de DC en una

Nota: Parte de los datos presentados fueron expuestos en el congreso (conjunto) de la Sociedades Catalana, Española y Europea de Geriatría y Gerontología, en Barcelona (junio de 2003). 